ARTICLE

Received 3 Feb 2014 | Accepted 6 Mar 2014 | Published 1 Apr $2014 \quad$ DOl: 10.1038/ncomms4576

\title{
Microlens arrays in the complex visual system of Cretaceous echinoderms
}

Przemysław Gorzelak , Mariusz A. Salamon², Rafał Lach², Michał Loba ${ }^{3}$ \& Bruno Ferré 4

It has long been assumed that photosensitivity in echinoderms is mainly related to diffuse photoreception mediated by photosensitive regions embedded within the dermis. Recent studies, however, have shown that some extant echinoderms may also display modified ossicles with microlenses acting as sophisticated photosensory organs. Thanks to their remarkable properties, these calcitic microlenses serve as an inspiration for scientists across various disciplines among which bio-inspired engineering. However, the evolutionary origins of these microlenses remain obscure. Here we provide microstructural evidence showing that analogous spherical calcitic lenses had been acquired in some brittle stars and starfish of Poland by the Late Cretaceous (Campanian, $79 \mathrm{Ma}$ ). Specimens from Poland described here had a highly developed visual system similar to that of modern forms. We suggest that such an optimization of echinoderm skeletons for both mechanical and optical purposes reflects escalation-related adaptation to increased predation pressure during the so-called Mesozoic Marine Revolution.

\footnotetext{
${ }^{1}$ Department of Biogeology, Institute of Paleobiology, Polish Academy of Sciences, Twarda Street 51/55, 00-818 Warsaw, Poland. ${ }^{2}$ Department of Palaeontology and Biostratigraphy, Faculty of Earth Sciences, University of Silesia, Będzińska Street 60, 41-200 Sosnowiec, Poland. ${ }^{3}$ Faculty of Geology, University of Warsaw, Żwirki i Wigury 93, 02-089 Warsaw, Poland. ${ }^{4}$ Dame du Lac 213, 3 rue Henri Barbusse, F-76300 Sotteville-lès-Rouen, France. Correspondence and requests for materials should be addressed to P.G. (email: pgorzelak@twarda.pan.pl).
} 
A mong echinoderms, discrete photoreceptive organs with putative image-forming capacity are only known to date in some starfish and one sea cucumber species ${ }^{1-3}$. However, some other echinoderms display a wide range of different behavioural and physiological responses to light ${ }^{4-7}$. Despite the lack of any direct evidence, the photosensitivity of these animals has long been alleged to 'diffuse' dermal photoreceptors capable to detect the overall variation in the illumination level ${ }^{8}$. However, there have been major recent advances in our understanding of photoreceptor cells in echinoderms, thanks to the genome sequencing of the purple sea urchin Strongylocentrotus purpuratus ${ }^{9,10}$. Latter studies evidenced a unique system of photoreceptors in sea urchin tube feet: its compact skeleton deploys numerous compound eye units acting as a whole as a screening device. Such a network of eye units provides the sea urchin with a directional vision. Recently, compound eyes devoid of true optics enabling low-resolution vision were documented in starfish species ${ }^{3}$.

In addition to diffuse photoreceptors embedded within soft tissues, ocular microstructures, conceivably with the function of a compound eye, have also been reported in some brittle stars. For instance, extant photosensitive Ophiocoma wendtii displays calcitic ossicles with optically clear spherical microstructures and migrating screening pigments both acting, respectively, as sophisticated lenses and filters ${ }^{11}$. Such calcitic microlenses display unusual optical properties directing and focusing the light on the underlying neural receptors ${ }^{12}$. Similar lens-like microstructures (probably with the same function), the so-called 'glassy tubercles', were observed in some recent starfish species ${ }^{13,14}$.

Surprisingly, despite an extensive fossil record of echinoderms, no study has dealt so far with the fine-scale analysis of lens-like microstructures in fossil echinoderms. Here we report analogous ocular microstructures in Late Cretaceous (Campanian) brittle stars and starfish. Our findings unveil the role of these lens-like microstructures in Late Cretaceous echinoderms and suggest that the complex visual system in echinoderms had been already acquired in the Late Cretaceous.

\section{Results}

Geologic setting. Echinoderm specimens with microlenses were collected from an abandoned quarry in Rzeżuśnia (Southern Poland, coordinates $50^{\circ} 20^{\prime} 10^{\prime \prime} \mathrm{N}, 19^{\circ} 58^{\prime} 16^{\prime \prime} \mathrm{E}$; Fig. 1a-c). This area belongs to the Miechów Trough as part of the so-called
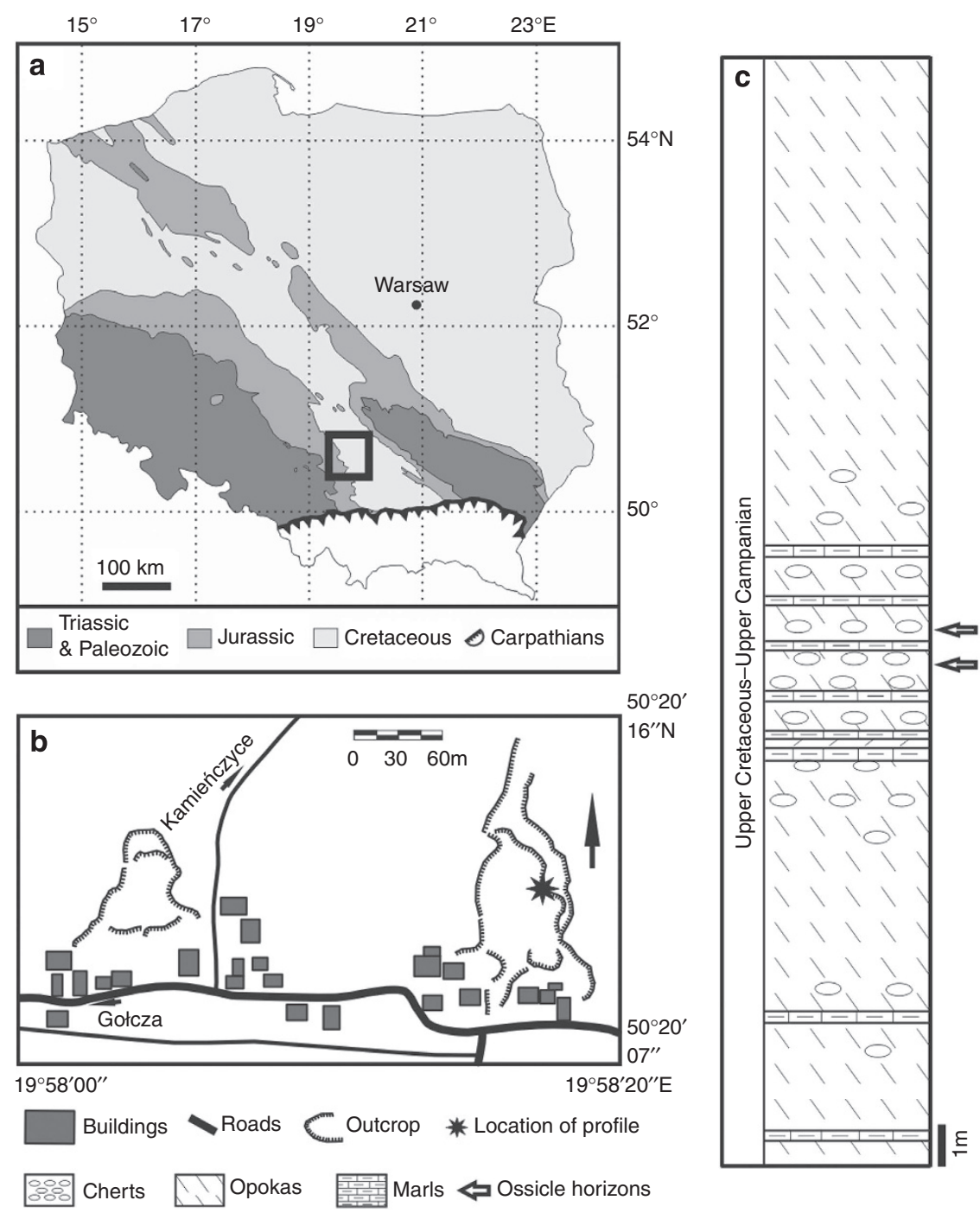

Figure 1 | Location map. (a) Schematic geological map of Poland and location of investigated area. (b) Outcrop location within investigated area. (c) Schematic lithological section of the Upper Campanian sediments (zones: Inoceramus azerbaydajensis-I. vorhelmensis, Patagiosites stobaei/Galeola basiplana and Galerites vulgaris/Galeola basiplana ${ }^{17}$ ) exposed in the Rzeżuśnia Quarry, arrows = sample location. 


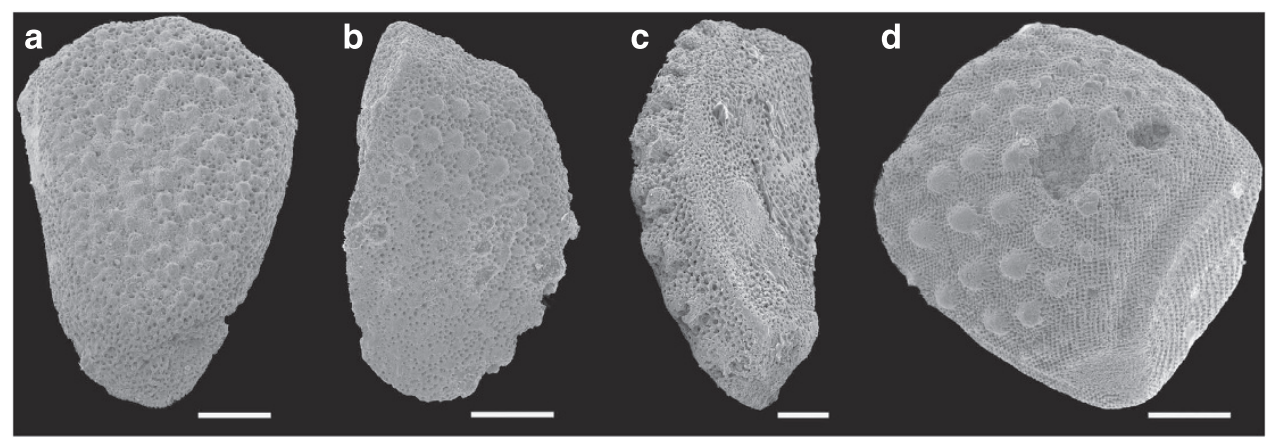

Figure 2 | Isolated ossicles of brittle stars and of starfish from the Upper Campanian (Upper Cretaceous) of Poland. The images are scanning electron micrographs (SEM). (a) Radial shield of Stegophiura? (dorsal view). (b) Lateral arm plate (LAP) of Stegophiura? (dorsal view). (c) LAP of Stegophiura? (inner-oblique view). (d) Starfish marginal plate (dorsal view). Scale bar, $500 \mu \mathrm{m}$.
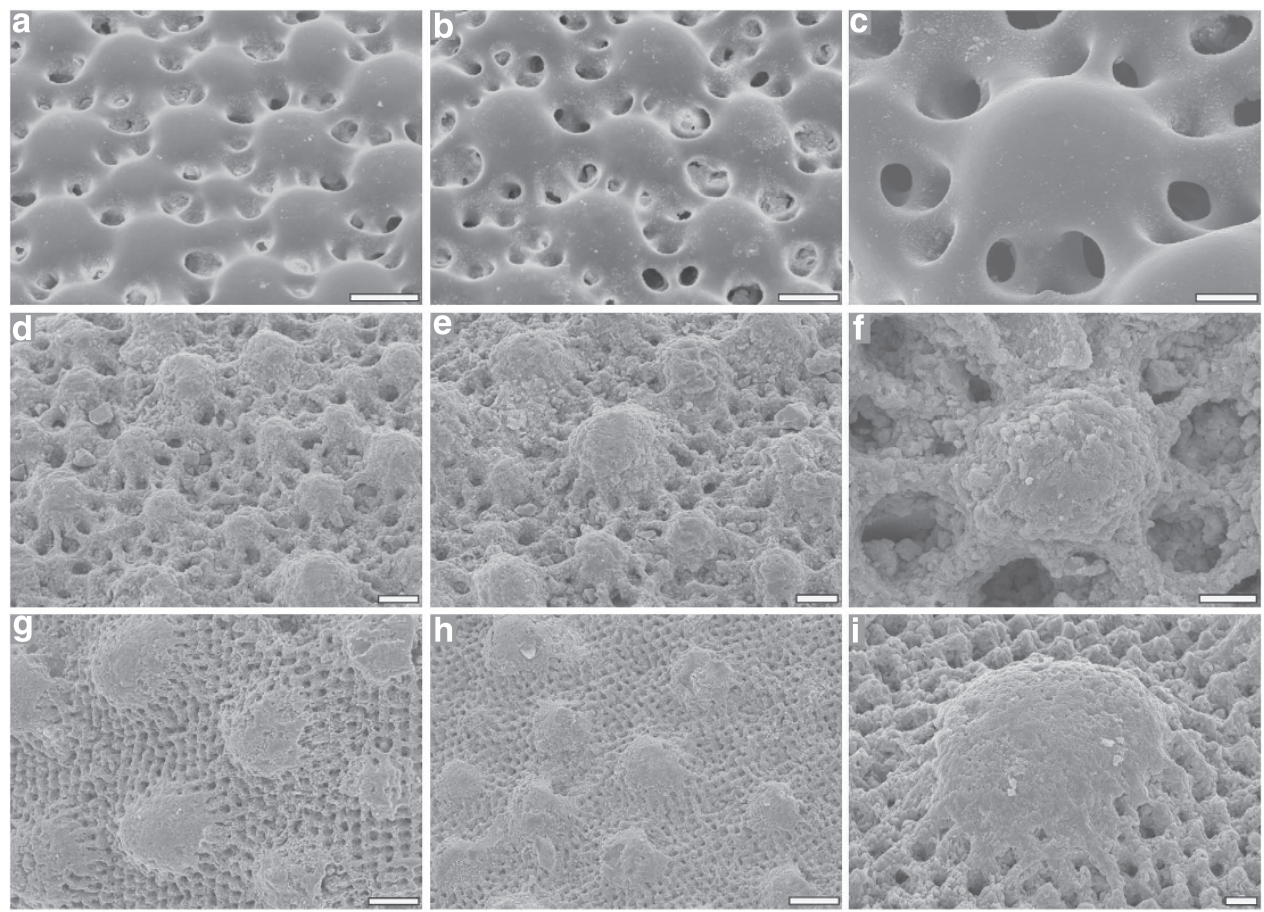

Figure 3 | Skeletal lens-like microstructure of extant and fossil echinoderms. The images are scanning electron micrographs (SEM). (a) Dorsal arm plate (DAP) of O. wendtii. (b) Lateral arm plate (LAP) of O. wendtii (c) Single lens of O. wendtii. (d) Radial shield of Late Cretaceous brittle star Stegophiura? (e) LAP of Late Cretaceous brittle star Stegophiura? (f) Single lens of the Late Cretaceous brittle star Stegophiura? (g,h) Marginal plate of Late Cretaceous starfish. (i) Single lens of the Late Cretaceous starfish. Scale bar, $50 \mu \mathrm{m}(\mathbf{a}, \mathbf{b}, \mathbf{d}, \mathbf{e}), 25 \mu \mathrm{m}(\mathbf{c}, \mathbf{f}, \mathbf{i})$ and $100 \mu \mathrm{m}(\mathbf{g}, \mathbf{h})$.

Szczecin-Łódź-Miechów synclinorium ${ }^{15}$. The exposed Cretaceous sequence comprises nearly $20 \mathrm{~m}$ of Upper Campanian ( 79 Ma) opoka (= calcarenite), marls and cherts ${ }^{16,17}$.

Morphology and microstructure of brittle star plates. A lens-like microstructure is observed on the aboral surfaces of 17 brittle star and starfish ossicles. The available brittle star plates consist of radial shields and lateral arm plates (LAPs), tentatively assigned to Stegophiura? of the family Ophiuridae ${ }^{18,19}$ (Fig. 2a-c). The isolated radial shields are generally robust, triangular and with rounded edges. Their surface comprises an array of closely packed hemispheres (Fig. 3d,f). These are the upper halves of almost spherical calcite structures that are relatively uniform in size and shape (Table 1), and are very similar to the lenses in the extant photosensitive species $O$. wendtii (Fig. 3a-c, Table 1). LAPs are also robust and massive, especially in the most proximal part. Their articulation spurs are weakly developed and hardly visible near the distal edge of the inner surface. Their distal margins display at least nine spine articulations that are relatively high, protruding and bilobate. Of these lobes, the first (probably dorsal) one is massive and bulge-like while the other one (probably ventral) is much thinner and surrounds the muscle opening slightly elongated ventro-distally. These isolated LAPs show a remarkable lens-like ornamentation similar to those of the radial shields (Fig. 3e). The lens diameters in Cretaceous and extant brittle stars cannot be statistically segregated from each other (the parametric $t$-test reports a probability of $P>0.05(n=20)$ for equality of the means of lens diameter, giving a non-significant difference).

Morphology and microstructure of starfish plates. The starfish ossicles are represented by various marginal plates (Fig. 2d). They mostly resemble those observed in Goniasteridae and Benthopectinidae ${ }^{20,21}$ : they are rather small, robust and blocky. 
Their outer faces are slightly curved, whereas the lateral faces are parallel to each other, vertical and slightly concave. In these starfish ossicles, the labyrinthic stereom with $10-15 \mu \mathrm{m}$ thick trabeculae and irregular pores extends into a regular array of lens-like spherical microstructures (Fig. 3g-i). The diameter of these probable lenses (Table 1) falls within the range of glassy tubercles in living starfish $(30-150 \mu \mathrm{m})^{13}$. Although similar oval tubercles (but never interpreted as ocular lenses) have been illustrated in other Mesozoic starfish species ${ }^{22,23}$, they are mostly

\section{Table 1 | Comparison of lens diameters in fossil and extant echinoderms.}

$\begin{array}{rll}37.9-83.9 & 61.5 & 12.2 \\ 30.3-80.6 & 57 & 12.1 \\ 33.8-88.3 & 63.7 & 17.2 \\ 40.1-88.1 & 64.6 & 14.2 \\ 83.3-135.2 & 107.5 & 15.8\end{array}$

DAP, dorsal arm plate; LAP, lateral arm plate.

Size range and average of diameters for each echinoderm plate were established from measurements of 20 lenses. made of dense labyrinthic stereom, not compact, imperforated and non-stereomic calcite as observed in the structures interpreted here as lenses. In cross-section, both starfish and brittle star lenses have a regular cone-like shape identical to those observed in living forms (Fig. 4b,e,h).

\section{Discussion}

In contrast with the wide range of calcitic and nonbiomineralized microlenses occurring in arthropods ${ }^{24-28}$, comparable eye-like structures in echinoderms remained unknown until their discovery in extant photosensitive brittle star species $O$. wendtii ${ }^{11,29}$. As highlighted by Aizenberg and Hendler ${ }^{12}$, thanks to their remarkable optical properties, the brittle star calcitic microlenses offer a high potential for bio-inspired engineering: lightweight, mechanically resistant, aberration free and birefringence free. However, a key question such as the origin of such sophisticated photosensory organs in echinoderms remains unanswered ${ }^{30}$. Although similar oval tubercles are known in Late Cretaceous (mostly Maastrichtian, $\sim 72.1-66 \mathrm{Ma}$ ) echinoderms ${ }^{18}$, they were never thoroughly analysed and interpreted as microlenses. Therefore, as a consequence, the present data are indeed the first ones to document this evolutionary innovation and provide a stimulus
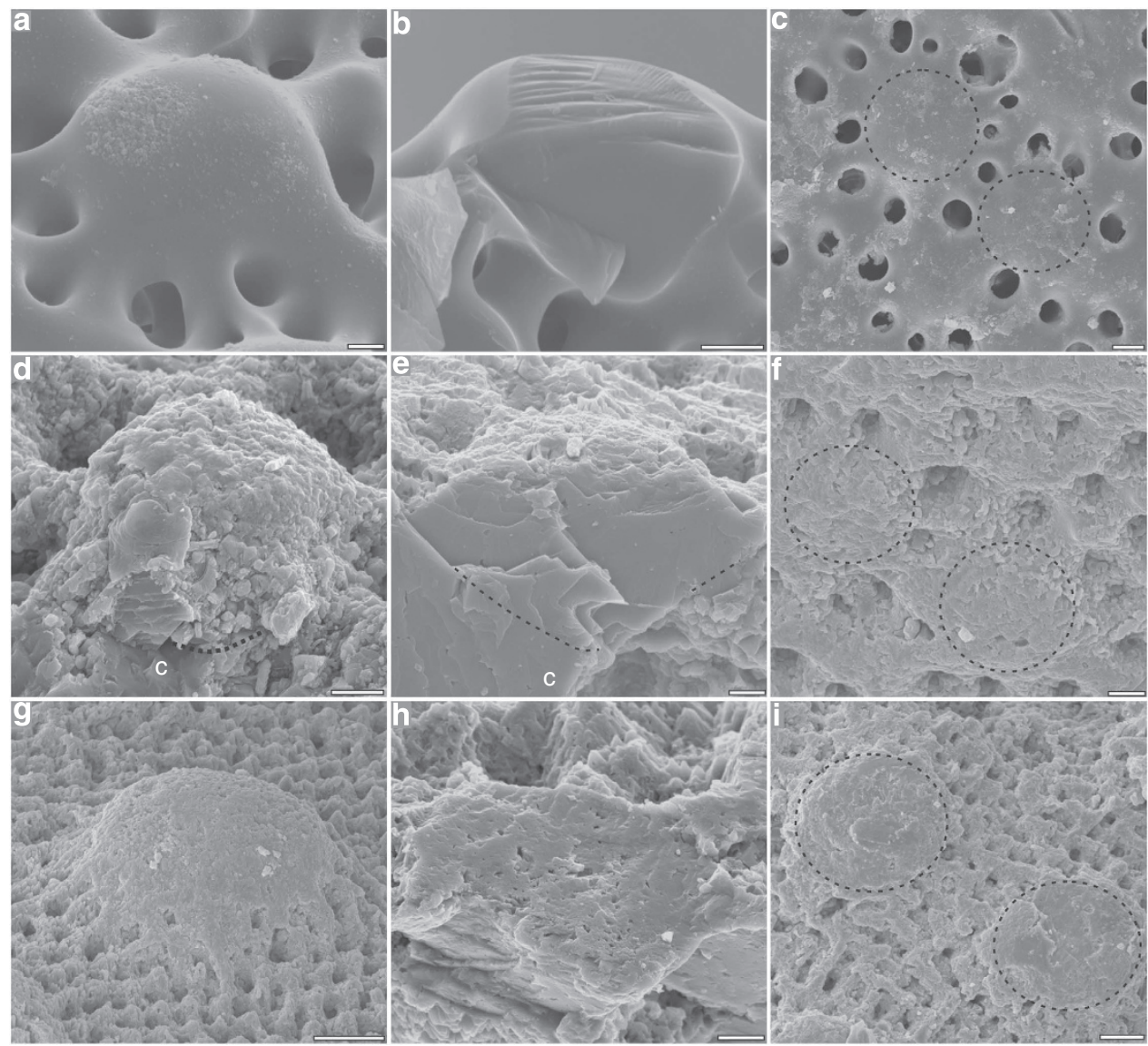

Figure 4 | Skeletal lens-like microstructures of extant and fossil echinoderms. The images are scanning electron micrographs (SEM). (a) Single lens in $O$. wendtii in oblique view. (b) Cross-section of a fractured lateral arm plate (LAP) of $O$. wendtii displaying an individual microlens. (c) Polished surface of LAP of $O$. wendtii showing the inner structure of individual microlenses (circles). (d) Single lens of the Late Cretaceous brittle star Stegophiura? in oblique view. (e) Cross-section of a fractured LAP of a Late Cretaceous brittle star Stegophiura? showing an individual microlens. (f) Polished surfaces of LAP of a Late Cretaceous brittle star Stegophiura? showing the inner structure of individual microlenses (circles). (g) Single lens of a Late Cretaceous starfish in oblique-lateral view. (h) Cross-section of a fractured marginal plate of a Late Cretaceous starfish showing an individual microlens. (i) Polished surfaces of a marginal plate of a Late Cretaceous starfish showing the inner structure of individual microlenses (circles). Dotted lines in $\mathbf{d}$ and $\mathbf{e}$ delineate the contact between lenses and carbonate cement infills (c). Scale bar, $10 \mu \mathrm{m}(\mathbf{a}, \mathbf{b}, \mathbf{d}, \mathbf{e}, \mathbf{h}) ; 50 \mu \mathrm{m}(\mathbf{g})$; and $20 \mu \mathrm{m}(\mathbf{c}, \mathbf{f}, \mathbf{i})$. 
for a line of future in-depth microstructural investigation of other fossil echinoderms of different age.

Despite some diagenetic alteration, the overall morphology of the stereom and microlenses of the ossicles at hand is well preserved and similar to those in living photosensitive relatives. Therefore, in the present state of art and to our knowledge, these fossil specimens represent the earliest so far microanatomical evidence for the occurrence of a highly developed vision in Late Cretaceous echinoderms. Interestingly, it suggests that similar lens-like microstructures occurred in various echinoderm clades in the Late Cretaceous. The question concerning why brittle stars and starfish optimized their skeletons for optical functions is still open. However, it seems probable that the parallel occurrence of these visual systems in Late Cretaceous echinoderms could have been a response to the increased predation pressure during the Mesozoic Marine Revolution ${ }^{30-33}$. During this period, there was a large-scale diversification of durophagous and grazing predators, such as teleost fishes and decapod crustaceans that is considered to have induced evolutionary changes in benthic marine communities $^{31}$. Our findings highlight the magnitude of antipredatory innovations already achieved in Late Cretaceous. This predation hypothesis is consistent with recent observations of $O$. wendtii quickly escaping from predators into dark crevices: a high performance photosensitive organ is highly advantageous in terms of survival in natural habitats ${ }^{34}$.

\section{Methods}

Sample collection. During spring and summer 2007 and 2012, several bulk samples of $\sim 25 \mathrm{~kg}$ were taken from the middle part of the Upper Campanian section in Rzeżuśnia quarry (Fig. 1c). They were processed through up to 10 soaking-and-thawing cycles (lowest temperature $\sim-19^{\circ} \mathrm{C}$ and boiled in a Glauber salt solution). All the samples were then washed and successively sieved (mesh sizes: $1.0,0.5$ and $0.315 \mathrm{~mm}$ ). The residue material was finally dried at up to $\sim 220^{\circ} \mathrm{C}$. Echinoderm ossicles were picked under a stereoscopic microscope. The studied material is housed at the Department of Earth Sciences, University of Silesia, Poland, under registration numbers GIUS 9-3623/As/1-350.

\section{Microstructural analyses of echinoderm skeletons. Figured ossicles were} photographed with a Phillips XL-20 scanning electron microscope (SEM) at the Institute of Paleobiology of the Polish Academy of Sciences in Warsaw. Lens dimensions were measured directly from SEM photographs. For comparison purpose, the ossicles of a recent photosensitive species $O$. wendtii from southeastern Florida displaying lens-like microstructure were also SEM investigated. In this case, the soft tissues were removed by soaking in a $5 \%$ sodium hypochlorite solution for $24 \mathrm{~h}$ at room temperature. The data were statistically analysed using PAST 2.02 software ${ }^{35}$. The lens distribution is not significantly nonnormal for any of the ossicles (the Shapiro-Wilk test, $P>0.05$ ); thus, we preferably used a parametric $t$-test for statistical comparison between fossil and extant materials. Nevertheless, the non-parametric Mann-Whitney test also reports a probability of $P>0.05(n=20)$ for equality of the medians of lens diameter, giving a non-significant difference.

The three-dimensional microstructure of selected ossicles was revealed either in fractures or in thin sections.

\section{References}

1. Yamamoto, M. \& Yoshida, M. Fine structure of the ocelli of a synaptid holothurian, Opheodesoma spectabilis, and the effects of light and darkness. Zoomorphologie 90, 1-17 (1978)

2. Smith, J. E. On the nervous system of the starfish Marthasterias glacialis. Phil. Trans. R. Soc. Lond. B 227, 111-173 (1937).

3. Garm, A. \& Nilsson, D. E. Visual navigation in starfish: first evidence for the use of vision and eyes in starfish. Proc. R. Soc. B 281, 2013-3011 (2014).

4. Millot, N. \& Yoshida, M. The Photosensitivity of the sea echinoid Diadema antillarum Phillipi: responses to increases in light intensity. Proc. Zool. Soc. Lond. 133, 67-71 (1958).

5. Yoshida, M. in Physiology of Echinodermata (ed. Boolootian, R. A.) (John Wiley \& Sons, 1966)

6. Reese, E. S. in Physiology of Echinodermata (ed. Boolootian, R. A.) (John Wiley \& Sons, 1966.

7. Moore, A. \& Cobb, J. L. S. Neurophysiological studies on photic responses in Ophiura ophiura. Comp. Biochem. Physiol. A 80, 11-16 (1985).

8. Blevins, E. \& Johnsen, S. Spatial vision in the Echinoid genus Echinometra. J. Exp. Biol. 207, 4249-4253 (2004).
9. Lesser, M. P., Carleton, K. L., Bottger, S. A., Barry, T. M. \& Walker, C. W. Sea urchin tube feet are photosensory organs that express a rhabdomeric-like opsin and PAX6. Proc. R. Soc. B 278, 3371-3379 (2011).

10. Ullrich-Lüter, E. M., Dupont, S., Arboleda, E., Hausen, H. \& Arnone, M. I. Unique system of photoreceptors in sea urchin tube feet. Proc. Natl Acad. Sci. USA 108, 8367-8372 (2011).

11. Aizenberg, J., Tkachenko, A., Weiner, S., Addadi, L. \& Hendler, G. Calcitic microlenses as part of the photoreceptor system in brittlestars. Nature 412, 819-822 (2001).

12. Aizenberg, J. \& Hendler, G. Designing efficient microlens arrays: lessons from nature. J. Mater. Chem. 14, 2066-2072 (2004).

13. Dubois, P. \& Hayt, S. Ultrastructure des ossicules d'échinodermes à stéréome non perforé. in Echinoderm Research (eds De Ridder C., Dubois P., Lahaye M.-C. \& Jangoux M.) 217-223 (Balkema, 1990).

14. Mah, C. L. A phylogeny of Iconaster and Glyphodiscus (Goniasteridae; Valvatida; Asteroidea) with descriptions of four new species. Zoosystema 27, 131-167 (2005).

15. Cieśliński, S. in Budowa Geologiczna Polski-Mezozoik (Wyd. Geol., 1973).

16. Świerczewska-Gładysz, E. \& Jurkowska, A. Occurrence and paleoecological significance of lyssacinosid sponges in the Upper Cretaceous deposits of southern Poland. Facies 59, 763-777 (2013).

17. Walaszczyk, I., Cobban, W. A., Wood, C. J. \& Kin, A. in Annie V. Dhondt Memorial Volume (eds Steurbaut, E., Jagt, J. W. M. \& Jagt-Yazykova, E. A.) (Bulletin de l'Institut royal des Sciences naturelles de Belgique, Sciences de la Terre, 2008).

18. Rasmussen, H. W. Cretaceous Asteroidea and Ophiuroidea With a Special Reference to the Species Found in Denmark Vol. 2, 1-134 (Denmarks Geologiske Undersøgelse, 1950).

19. Matsumoto, H. A new classification of Ophiuroidea: with description of genera and species. Proc. Acad. Nat. Sci. Philadelphia 67, 43-92 (1915).

20. Forbes, E. A history of British starfish and other animals of the class Echinodermata 1-267 (John Van Voorst, 1841).

21. Gale, A. Asteroidea (Echinodermata) from the Oxfordian (Late Jurassic) of Savigna, Départment [sic!] du Jura, France. Swiss J. Palaeontol. 130, 69-89 (2011).

22. Villier, L., Kutscher, M. \& Mah, C. h. L. Systematics and palaecology of middle Toarcian Asteroidea (Echinodermata) from the 'Seuil du Poitou', Western France. Geobios 37, 807-825 (2004).

23. Villier, L. Sea star ossicles from the Callovian black clays of the Łuków area, eastern Poland. Neues Jb. Geol. Paläont. Abh. 247, 147-160 (2008).

24. Towe, K. M. Trilobite eyes: calcified lenses in vivo. Science 179, 1007-1010 (1973).

25. Clarkson, E. N. K. \& Levi-Setti, R. Trilobite eyes and the optics of Descartes and Huygens. Nature 254, 663-667 (1975).

26. Torney, C., Lee, M. R. \& Owen, A. W. Microstructure and growth of the lenses of schizochroal trilobite eyes. Palaeontology doi:10.1111/pala.12088 (2013).

27. Zhao, F., Bottjer, D. J., Hu, S., Yin, Z. \& Zhu, M. Complexity and diversity of eyes in Early Cambrian ecosystems. Sci. Rep. 3, 2751 (2013).

28. Clarkson, E., Levi-Setti, R. \& Horvath, G. The eyes of trilobites: the oldest preserved visual system. Arthropod Struct. Dev. 35, 247-259 (2006).

29. Hendler, G. \& Byrne, M. Fine structure of the dorsal arm plate of Ophiocoma wendti (Echinodermata, Ophiuroidea). Zoomorphology 107, 261-272 (1987).

30. Singer, J. \& Neumann, C. h. 5th Arbeitstreffen deutschsprachiger Echinodermenforscher 31-32 (Stuttgart, Germany, 2013).

31. Vermeij, G. J. The Mesozoic marine revolution; evidence from snails, predators and grazers. Paleobiology 3, 245-258 (1977).

32. Oji, T., Ogaya, C. h. \& Sato, T. Increase of shell-crushing predation recorded in fossil shell fragmentation. Paleobiology 29, 520-526 (2003).

33. Gorzelak, P., Salamon, M. A. \& Baumiller, T. K. Predator-induced macroevolutionary trends in Mesozoic crinoids. Proc. Natl Acad. Sci. USA 109, 7004-7007 (2012).

34. Hendler, G. Brittlestar color-change and phototaxis (Echinodermata: Ophiuroidea: Ophiocomidae). Mar. Ecol. 5, 379-401 (1984).

35. Hammer, Ø., Harper, D. A. T. \& Ryan, P. D. PAST: Paleontological software package for education and data analysis. Palaeontol. Electron. 4, 9 (2001).

\section{Acknowledgements}

This work was completed while the first author was a recipient of a grant from the Polish National Science Centre (NCN) Grant number DEC-2011/03/N/ST10/04798. We thank Professor Charles G Messing (Nova Southeastern University) for providing the specimen of extant brittle star.

\section{Author contributions}

M.A.S. and R.L. carried out the fieldwork and collected the specimens. P.G. conducted microstructural analyses. All authors contributed to the discussion and writing of the paper. 


\section{Additional information}

Supplementary Information accompanies this paper at http://www.nature.com/

naturecommunications

Competing financial interests: The authors declare no competing financial interests.
Reprints and permission information is available online at http://npg.nature.com/ reprintsandpermissions/

How to cite this article: Gorzelak, P. et al. Microlens arrays in the complex visual system of Cretaceous echinoderms. Nat. Commun. 5:3576 doi: 10.1038/ncomms4576 (2014) 